\title{
Size distribution in the process of Lineament extraction.
}

\author{
土田 聡**, 山口 靖*** \\ 長谷 紘和 \\ Satoshi TSUCHIDA, Yasushi YAMAGUCHI \\ Hirokazu HASE
}

\begin{abstract}
Lineament analysis, made through the observation of remote sensing data, is encountered various bias effects. In this paper, the bias effects are analyzed firstly by grouping the process of lineament extraction into three stages, that is ; ground based effects (A-factor), image based effects (B-factor), and human effects (C-factor). These effects change the size distribution of lineaments. The distribution of the extracted lineaments can be formulated in the following equation.

$$
n_{4}(L) \fallingdotseq c^{\prime} \times L^{-(\mathrm{D}+1)} \times \int_{l \min }^{L} \frac{1}{\sqrt{2 \pi} \sigma l} \times \exp \left[-\frac{(\log l-\mu)^{2}}{2 \sigma^{2}}\right] d l
$$

where $\mathrm{n}_{4}(L)$ is the frequency of extracted lineaments with length $L . l$ is the recognizable length of a lineament whose actual length is $L$. $D$ is the fractal dimension. $c^{\prime}, \sigma$ and $\mu$ are constants.
\end{abstract}

\section{1.はじめに}

画像デー夕から認識抽出されるリニアメントは, 地 殼中の断裂の反映であるとみなされている。リニアメ ントのサイズ分布は断裂の規模別頻度分布と類似して おり，リニアメントが断裂に由来することの証拠の一

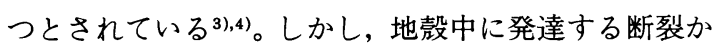
ら画像上で認識抽出されるリニアメントに至るまでに は, 断裂の地形への表現・地形の画像化・画像からの リニアメントの認識などといった多くの過程が含まれ ている。

リニアメントのサイズ分布を細部にわたって再検討 した結果，断裂の規模別頻度分布との差異が見いださ れた。本研究においては，断裂からリニアメントに至 るまでの過程において，その累積サイズ分布およびサ イズ分布（本論文においては，サイズ分布・累積サズ 分布を次のように使い分ける。サイズ分布は, 横軸に

* 日本写真測量学会昭和62年度秋季講演会1)および ISPRS KYOTO' $88^{2}$ にて一部を発表。

** 早稲田大学理工学研究科

$* * *$ 工業技術院地質調查所

「写真測量とリモートセンシング」Vol. 28, No. 2, 1989
長さ, 縦軸にその長さの頻度を表わす。累積サイズ分 布は，横軸は同じく長さ，そして縦軸にはその長さよ りも長いリニアメントの総数を表わす）の特徵につい て述べその変化を理論的に考察する。これらの考察を 行なうことによって，統計解析によるリニアメントの 定量的評価の可能性を広げられることが期待される。

\section{2. 方法}

\section{1 リニアメントの定義}

リニアメントという用語は, Hobbsによる提唱5)以 来, 広く用いられてきてはいるが，その定義について は，各人の考之方の違いが大きく，かなりの混乱を招 いている。類似用語（例之ば, linear, lineation など） が汇濫し, 新しい拡大解釈が頻繁になされ,ランドサッ トリニアメントやレーダリニアメントなどという表現 も混乱の一因となっている。しかし，O' Leary らによ る用語の再定義副がなされてからは，リニアメントを 「地殻の構造を反映すると考えられる面的広がりを有 する線状の地形特徵」とする定義が広く受け入れられ るようになった。Glossary of Geology の第三版》にお いても，基本的にこの定義を用いているため，本論文 も，これに従うこととする。 


\section{表 1 使用画像}

\begin{tabular}{|l|c|c|r|r|l|l|}
\hline \multicolumn{1}{|c|}{ 画 像 } & 縮 尺 & 摄影年月日 & 撮像高度 & 解像度 & 対象波長 & \multicolumn{1}{|c|}{ 備 考 } \\
\hline 空中写真 & $1: 20,000$ & 1967.10 .1 & $5000 \mathrm{~m}$ & $2-3 \mathrm{~m}$ & 可視域 & $\begin{array}{l}\text { 白量プリント } \\
\text { 実体視観察 }\end{array}$ \\
\hline レーダ画像 & $1: 200,000$ & 1981.8 & $11500 \mathrm{~m}$ & $12 \mathrm{~m}$ & $9.6 \mathrm{GHz}$ & $\begin{array}{l}\text { W-look, } \\
\text { マイクロ波 X X゙ンド }\end{array}$ \\
\hline ランドサット画像 & $1 ; 500,000$ & 1980.7 .19 & $918 \mathrm{~km}$ & $80 \mathrm{~m}$ & $\begin{array}{l}\text { 可視域 } \\
\text { 近赤外域 }\end{array}$ & $\begin{array}{l}\text { フォールスカラー } \\
\text { MSS 4,5,7バンド }\end{array}$ \\
\hline
\end{tabular}

\section{2 使用画像}

リニアメントの判読・抽出には, 縮尺 2 万分の 1 の 空中写真 (日本林業技術協会が販売しているもの) 20 万分の 1 の合成開ロレーダ画像（新エネルギー総合開 発機構が取得・販売中のもの $\left.{ }^{8)}\right)$ および50万分の 1 ラン ドサット画像(同前)を使用した。各画像の詳細につい ては表 1 に示す。なお, ランドサット画像にはエッジ 強調処理 (ラプラシアン変換) が施されている。

\section{3 抽出方法}

リニアメントは, 空中写真・レーダ画像およびラン ドサット画像から肉眼判読により抽出した。抽出は, 著者のうちの一人(土田)が行なった。一本のリニアメ ントに注目して厳密な調查を行なう場合には, 客観性 という点からは複数の研究者によって抽出・比較検討 する方法が好ましい。しかし，リニアメントの抽出過 程を統計的に検討しようとする場合においては，むし ろ，一個人がそれぞれの基準を持って抽出した結果に 基づいて議論すべきであり，必ずしも複数の判読者を 必要としない。レーダ画像およびランドサット画像 では,一枚のシートで解析対象地域をカバーできたが, 空中写真では数10枚が必要であった。よって, 空中写 真におけるリニアメント抽出に当たっては各写真の撮 影条件・現像・焼付条件などの違いにより，写真ごと に判断結果の差異を生じる危険性がある。しかし，こ れらの条件による影響は, 今回は無視できるものと仮 定した。一方, 判読過程においても, 写真の枚数が多 くなると判読者に由来する判読結果の差異が生ずる。 例之ば，判読時間が写真ごとに違う場合には，時間を 長くかければ，より多くのリニアメントが抽出される ことになり, 複数の写真にわたって統計解析をする際 には問題となる。この危険性を小さくするために一枚 における抽出の所用時間を 10 分間に設定し，一時期に
同一条件下で抽出を行なった。

巳らに, 比較的短い ( $2 \mathrm{~km}$ 以下) 線状模様も機械 的にリニアメントとして抽出した。これは, 調査地域 が断裂の多い造山地帯に位置するために，比較的短い 地形的な線状模様も断裂の反映である可能性が高いと 考えられるためである。第 1 図は, 長さ約 $1 \mathrm{~km} の リ$ ニアメント（地質図上に断層としては現れていない） に注目し，断裂とリニアメントの関係について調査結 果を示したものである。この場合，断裂とは，それに 沿って (平行に) 地層の変位を認められる断層ではな く, 開口性の割れ目や，明瞭には変位の認められない 微小な割れ目のことを指す。リニアメントの位置に近 づくにつれて断裂の密度は增加していくことがわか る。このように, 本地域においては, 比較的規模の小 さなリニアメントも断裂の現れである可能性が大きい とみなされる。なお，リニアメントは必ずしも完全な 直線ではないが，累積サイズ分布・サイズ分布などに ついてのコンピュータ一処理のため, 直線に近似して ディジタイズした。

\section{4 解析対象地域}

解析対称範囲は, 北海道中西部大夕張地域に位置し, 総面積は約 $200 \mathrm{~km}^{2}$ である(第 2 図)。本地域内では シューパロ川およびその支流の沢が樹枝状または格子 状の水系パターンを示している。地質的には白亜系の 地層が広く分布し，その一般走向は N-S から NNE -SSW 方向で，傾斜は東に60 90度ほどである。これ らの地層は, 逆転単斜構造をなし, 東より下部蝦夷層 群・中部蝦夷層群・上部蝦夷層群・函㴊層群の順に分 布する。白亜系の東側には空知層群・変成岩類・蛇紋 岩が分布し, 白亚系との境界はNNE-SSW 系と WNW-ESE 系の断層からなっている。白亜系の西側 には第三系が分布する。 


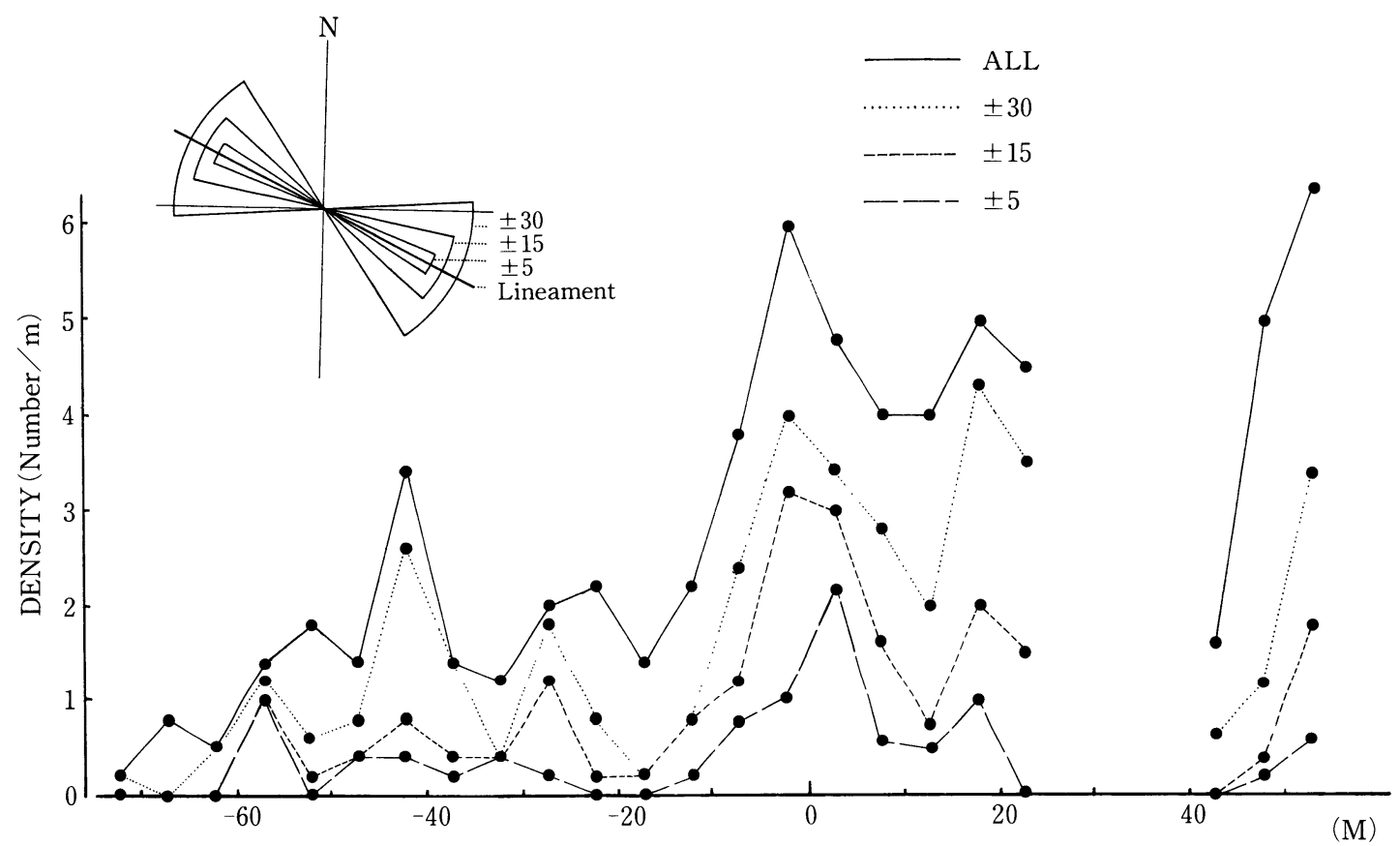

第 1 図リニアメントと直交する測線に沿った断裂密度(北海道大夕張地域北部)。

$0 \mathrm{~m}$ は, 測線とりニアメントの交差位置。図中の各点線は, 左上のローズダイアグラムに示す方向範囲 の断裂のみを対象にした断裂密度。

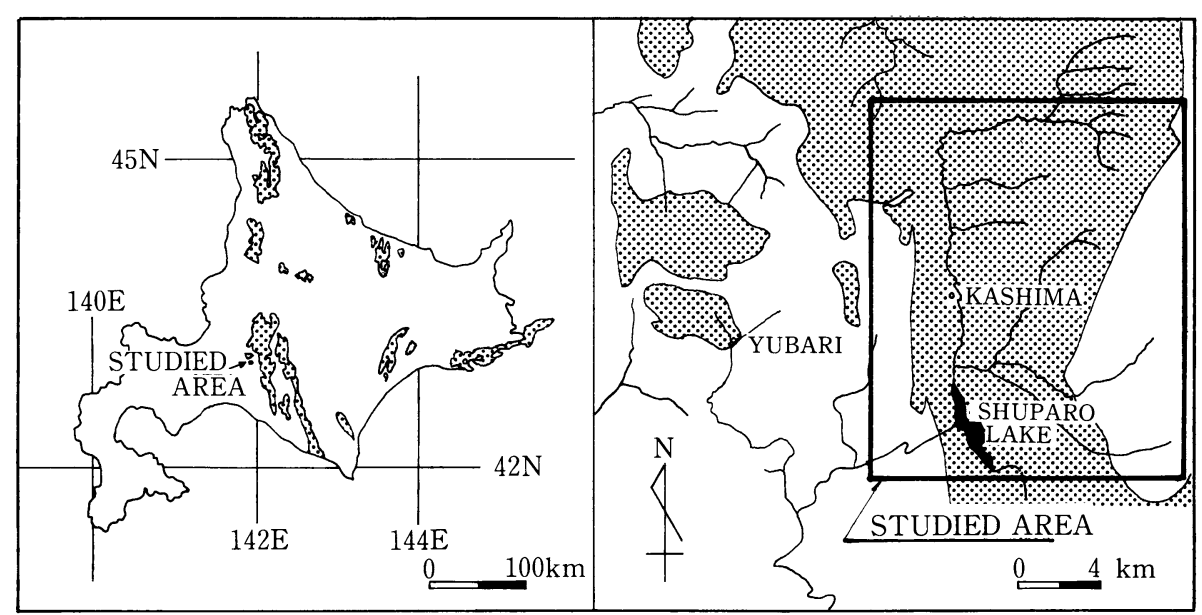

第 2 図 解析対象地域および白亜系分布地域

3.リニアメント出現モデル（リニアメン トの理論的サイズ分布）

\section{1 リニアメントの出現とその頻度}

リニアメントの抽出過程における様々な影響をまと めると，第 3 困に示したようになる。地表の断裂から
リニアメントに至るまでの抽出過程を 3 段階であると 考之る。各段階の間の 4 つの集団は, 各々, 断裂系(第 1 集団), 地表面上のリニアメント (第 2 集団), 画像 上のリニアメント（第 3 集団）および認識抽出される リニアメント（第 4 集団）である。ここで 3 つの抽出 過程における影響を各々, グランドベースエフェクト (A-factor)，イメージベースエフェクト（B-factor） 


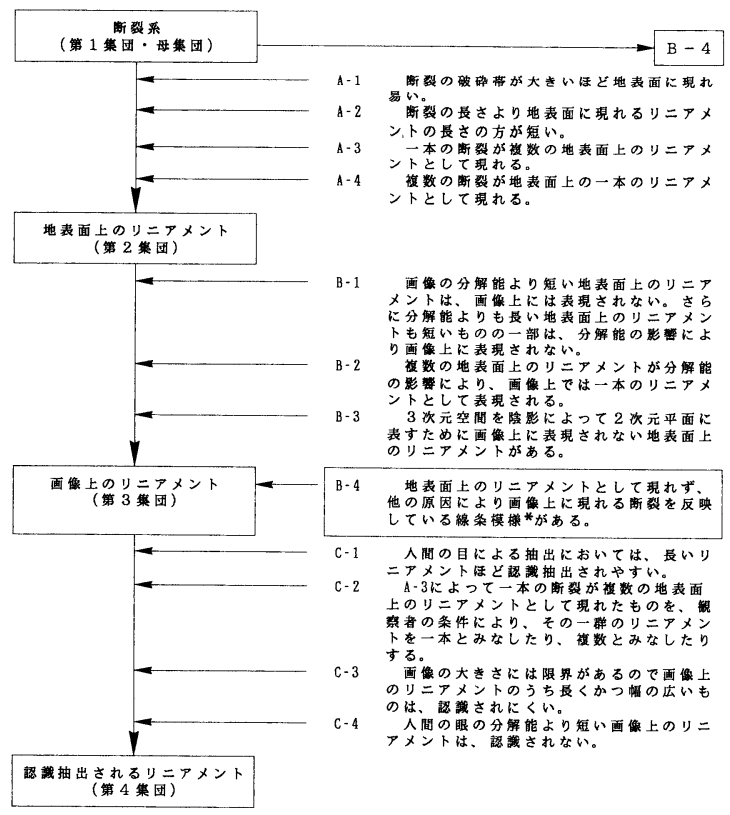

第 3 図断裂系の集団から認識抽出されるリニアメントの 集団に至る過程。

*リニアメントの定義は, 現在「地殼構造を反映 すると考えられる画的広がり有する線条の地形特 微」7),9)となっている。よって画像上に表現されて いる線条模様が，たと之断裂をあらわしていても 地形的 (topographic)に表現されていなけへば, リニアメントと記載することはできない。

およびヒューマンエフェクト（C-factor）と呼ぶこと にする。

以下，これら 4 つの集団におけるリニアメントの累 積サイズ分布・サイズ分布の違いについて述べる。

\section{2 断裂系（第 1 集団）}

第 1 集団の累積サイズ分布については，実験的・経 験的なデータにより知られている。この第 1 集団にお ける理想的な規模別頻度分布（累積サイズ分布）は第 4 図(a)のように表される。物質の破壊過程において， その累積サイズ分布におけるフラクタル次元 $D$ （自己 相似的なランダムな形や現象を定量的に表すための最 も基本的な量。ここでは，フラクタル次元の概念を拡 張 ${ }^{10), 11)}$ して用いている。よって，本論においては，第 4 図のように累積サイズ分布を両対数グラフ上で表し た場合のその傾きの大きさを指すことになる）は，ほ ぼ 2 になることが報告されている。例えば，岩石の破

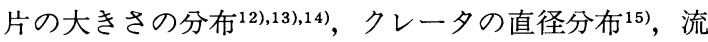
水の大きさ分布 ${ }^{16)}$, 地震の規模分布 ${ }^{17), 18), 19}$ および岩盤

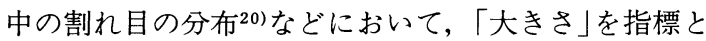

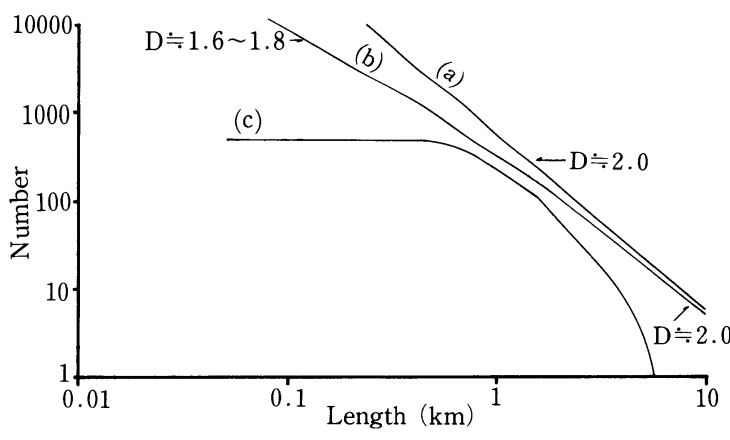

第 4 図 第 1 集団(a), 第 2 集団(b)及び第 4 集団(c)の累積サ イズ分布

した場合のフラクタル次元はすべて 2 に近い值を示 す。

割れ目については，露頭上の割れ目だけに注目した 場合， $D$ は 2 より 小さな值（1.6 1.8が多い）を示 すが，「大きさ」の測定対象範囲をより広範囲なレベル （地質図レベル）まで広げた場合には $D \fallingdotseq 2$ となる20)。 また, 地震学においては, Gutenberg-Richterの式21) から以下のように地震断層の長さと頻度との関係を求 めている17),18),19)。

地震のマグニチュードを $M$, 頻度を $n_{1}(M)$, 累積頻 度を $N_{1}(M)$ と置けば, Gutenbeg-Richterの式が経験 的に成り立つ。

$$
\begin{aligned}
& \log N_{1}(M)=a-b M \\
& \log n_{1}(M)=a^{\prime}-b M
\end{aligned}
$$

ただし， $a, a ， b$ は定数で, $n_{1}(M)=-N_{1}(M) / d M$ である。つまり, $n_{1}(M)$ がマグニチュード $M$ の地震の サイズ分布, $N_{1}(M)$ がその累積サイズ分布である。 $M$ は，エネルギー $E$ に換算すれば，

$M \propto 2 / 3 \times \log E$

であり，(1)・(1')と (2)より, エネルギー $E$ と頻度の関 係は

$$
\begin{aligned}
& \log N_{1}(E)=\text { 定数 }-k \times \log E \\
& \log n_{1}(E)=\text { 定数 }-(k+1) \times \log E
\end{aligned}
$$
または，

$$
\begin{aligned}
& N_{1}(E)=\text { 定数 } \times E^{-k} \\
& n_{1}(E)=\text { 定数 } \times E^{-(k+1)}
\end{aligned}
$$

ここで, $k=b / 1.5$ である。エネルギー $E$ は 3 次元の物 理量なので, 1 次元の物理量である長さ $L$ で表せば,

$$
\begin{aligned}
& \log N_{1}(L)=\text { 定数 }-3 k \times \log L \\
& \log n_{1}(L)=\text { 定数 }-(3 k+1) \times \log L
\end{aligned}
$$
または,

$$
N_{1}(L)=\text { 定数 } \times L^{-3 k}
$$


$n_{1}(L)=$ 定数 $\times L^{-(3 k+1)}$

$\left(4 b^{\prime}\right)$

となる。 $b$ 值は, 経験的にほぼ 1 もしくは 1 よりもやや 小さい值を示すことが知られている。ここでは, $b \fallingdotseq 1$ とすると $(4 b)$ および $\left(4 b^{\prime}\right)$ は，

$$
\begin{aligned}
& N_{1}(L)=\text { 定数 } \times L^{-2} \\
& n_{1}(L)=\text { 定数 } \times L^{-3}
\end{aligned}
$$

となる。

これらのことより，断裂の累積サイズ分布およびサ イズ分布は両対数グラフにおいて右下がりの直線 $(D \fallingdotseq 2)$ として表される。

$$
\begin{aligned}
& N_{1}(L)=C \times L^{-\mathrm{D}} \\
& n_{1}(L)=c \times L^{-(\mathrm{D}+1)}
\end{aligned}
$$

$(C, c:$ 定数)

\section{3 地表面上のリニアメント（第 2 集団）}

第 6 図は, 空中写真, 合成開ロレーダ画像およびラ ンドサット画像から得られたそれぞれの累積サイズ分 布（第 5 図 $\mathrm{a} \sim \mathrm{c}$ ）を 1 つのグラフ上にまとめたもので ある。第 6 四の分布の包絡線をとった場合, その直線 状分布を示す部分は, 画像ごとの差異を取り除いたも のであり，第 2 集団の分布に近似できると推定される。 これは，異なるスケールでの解析結果を重合すれば, 適した範囲を相補し合うことにより，広い範囲の頻度 分布を得られるという考之 ${ }^{4), 20) に よ っ て い る 。 ~}$

この直線状分布を示す部分を直線で近似した場合の 傾き $D$ は 2 よ小さく, 第 6 困においては, ほぼ 1.7〜2.0の間に值を示す。

$$
\begin{aligned}
& N_{2}(L)=C^{\prime} \times L^{-\mathrm{D}} \\
& n_{2}(L)=c^{\prime} \times L^{-(\mathrm{D}+1)}
\end{aligned}
$$

( $C^{\prime}, c^{\prime}$ : 定数)

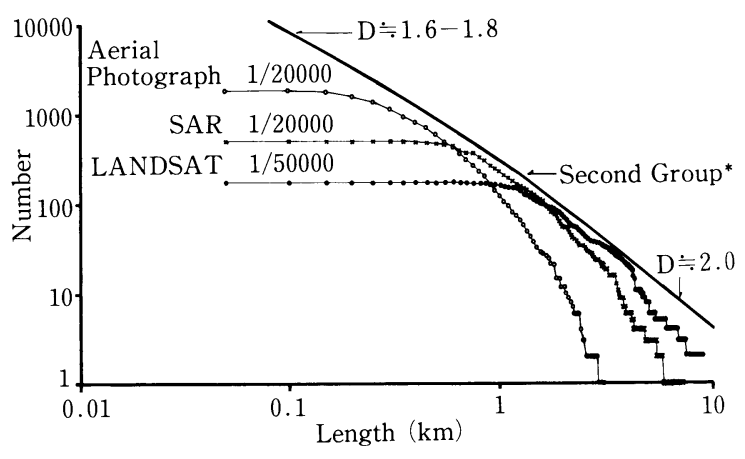

第 6 図 空中写真, 合成開ロレーダ画像 (SAR) 及びランド サット画像の果積サイズ分布およびこの3つの図よ り推定された第 2 集団 $(*)$ の累積サイズ分布。

*第 4 図(b)と同じ

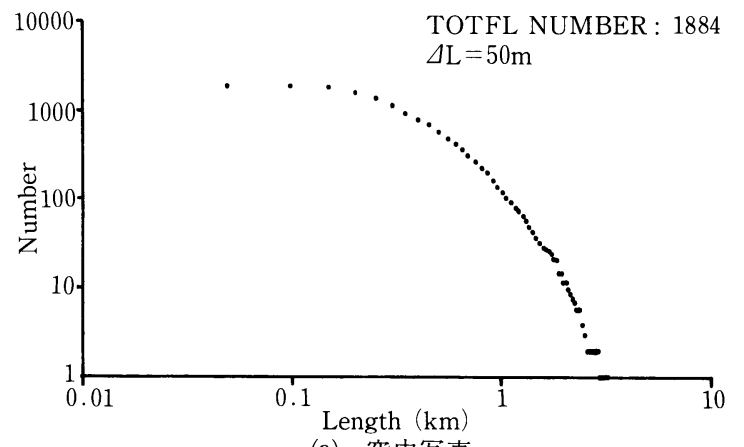

(a) 空中写真
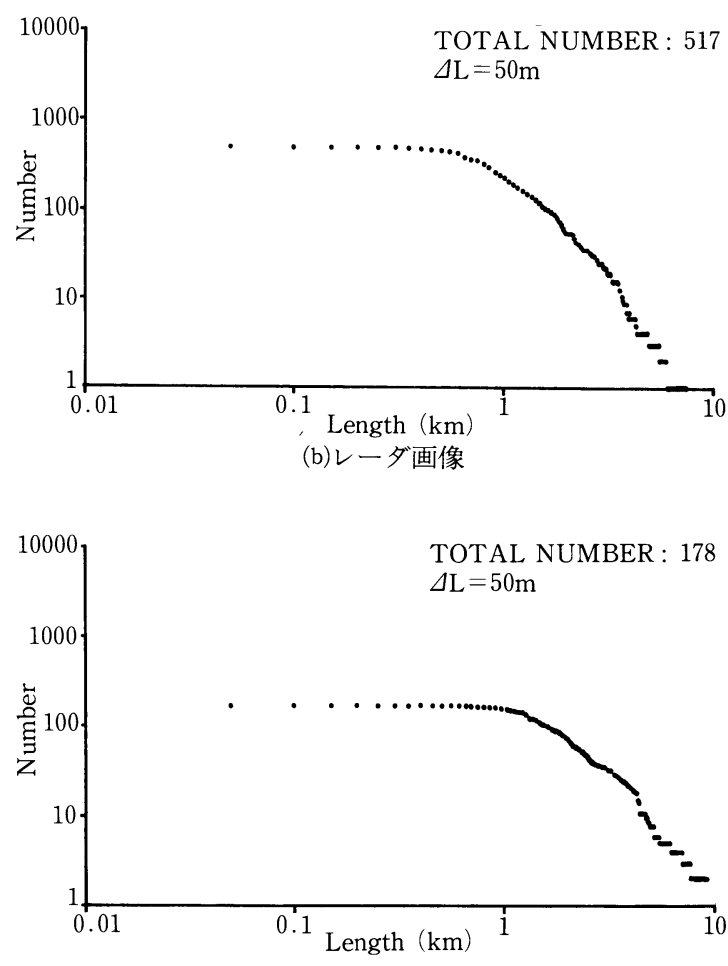

(c) ランドサット画像

第 5 図 北海道大夕張地域の各画像における累積サイズ分布

しかし，第 6 図の分布は厳密に考之ると直線状分布 ではなくやや上に凸の曲線分布となっている。第 1 集 団において直線分布を示していたものが，第 2 集団お いては上に凸の曲線を示すことは注目に値する。この 曲線の傾きから得られるフラクタル次元は，長さが長 い側では 2 に近く, 短い側では1.6〜 1.8 となっている。 短い側のフラクタル次元が，本来の次元数である 2 よ りも低くなっているのは, 短い断裂ほど地表面上のリ ニアメントとして現れにくいことを意味している。 


\section{4 画像上のリニアメント（第 3 集団）}

第 3 集団の累積サイズ分布を求めることは困難であ る。例えば，画像処理により，自動的に抽出された線 状模様は，第 3 集団に近いものと考えてもよい。しか し，現時点おいては，線状模様の自動抽出法そのもの について議論がされている段階であり，この論文での 議論に用いることのできるような信頼に足る第 3 集団 のリニアメントを提示できるとは言いがたい。

\section{5 認識抽出されるリニアメント（第 4 集団）}

長さ $L$ の画像上のリニアメントが認識抽出される 確率 $Q(L)$ は, リニアメントの長さ $L$ によって変化す る。人間の眼によって得られる情報は，ある一定の長 さまでは急激に増えるが，それ以降は緩やかな増加を 示すものと考えられる。したがって, $Q(L)$ は長さの増 加により単調に増加するが，その増加率 $d Q / d L$ はあ る長さまでは増大し，それを越えると逆に減少する。 実際のデー夕の検討結果によれば，このような性格を 持つ確率 $Q(L)$ は，累積対数正規分布により最もよく 近似できることが経験的に知られている（第 7 図，第 8 困)。では，なぜ $Q(L)$ が累積対数正規分布で近似で

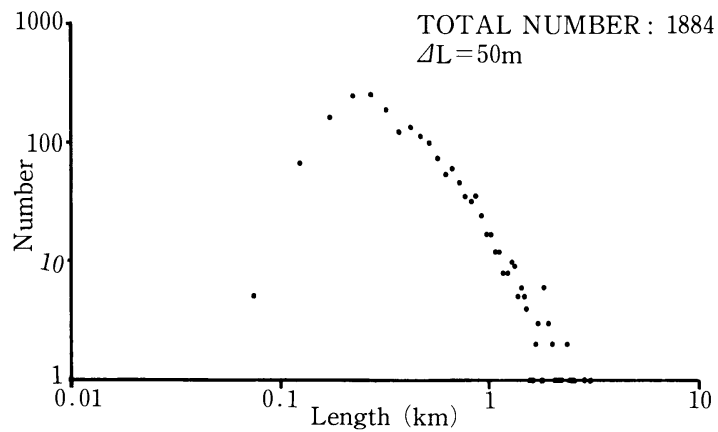

(a) 実測值

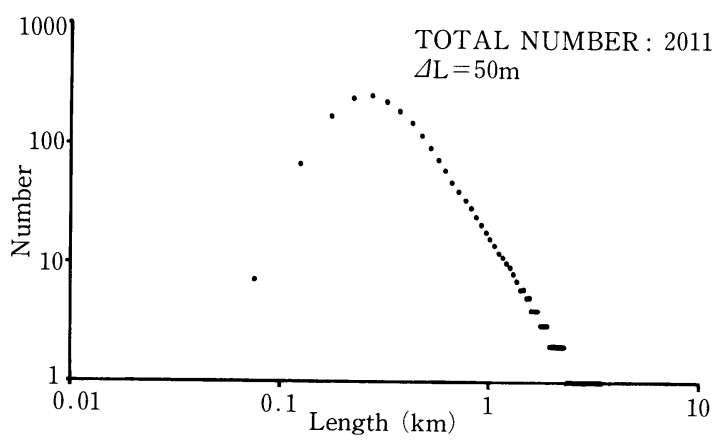

(b) 理論値

第 7 図 北海道大夕張地域の空中写真のサイズ分布とその 理論分布
きるかについて考察してみよう。

第 3 集団の長さ $L$ のリニアメントが第 4 集団のリ ニアメントして抽出されるか否かは, 明瞭な地形的特 徵を有する要素部分に基づいて判断されている（第 9 図)。こうした部分を要素 $l i($ セグメント $: \Sigma l i=l \leqq L)$ と呼ぶことにする。長さ $L$ のリアメントのうち, 前 記の要素 $l i$ 以外の部分は, 抽出するか否かを決定する ための判断基準となっていない部分である。ここで, 判断基準となった部分の長さの総計を $l(\Sigma l i)$ とする。 第 3 集団の長さ $L$ の 1 本のリニアメントが長さ $l$ の 情報によって画像から抽出される確率分布は，lの関 数とみなすことができ， $P(l)$ で表される。

$$
\int_{l_{\min }}^{\infty} P(l) d l=1
$$

$P(l)$ は，いくつかの独立した確率的事象（この場合は 様々な断層地形の画像上での表現）に分解できる。例 えば, $p 1$ ：ケルンバット・コルンがある。 $p 2$ : 三角末 端面がある， $p 3 ：$ 地すべりがある，…..などである。 これらの事象が独立ならば, $P(l)$ は乗法の公式に従 い，各々の事象の存在確率の積として表すことができ $P(l)=P(p 1) \times P(p 2) \times P(p 3) \times \cdots \cdots$

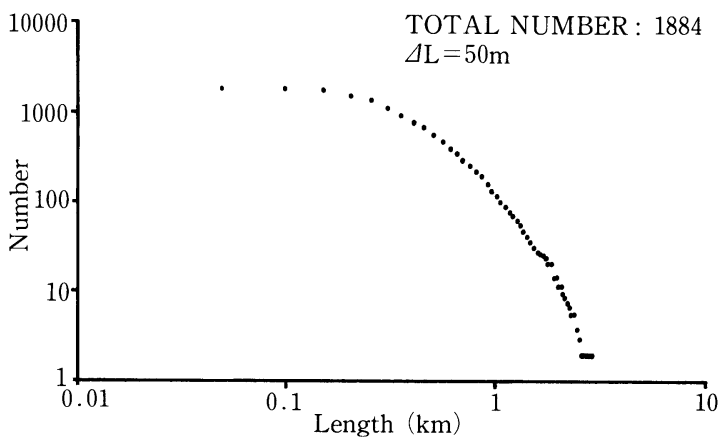

(a) 実測值

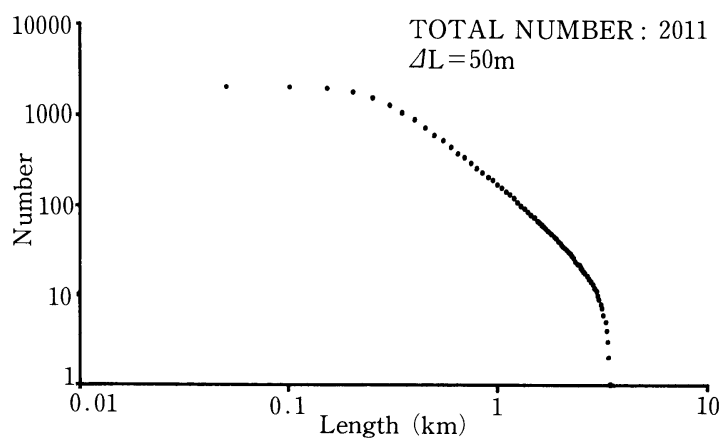

(b) 理論值

第 8 図 北海道大夕張地域の空中写真の累積サイズ分布と その理論分布 


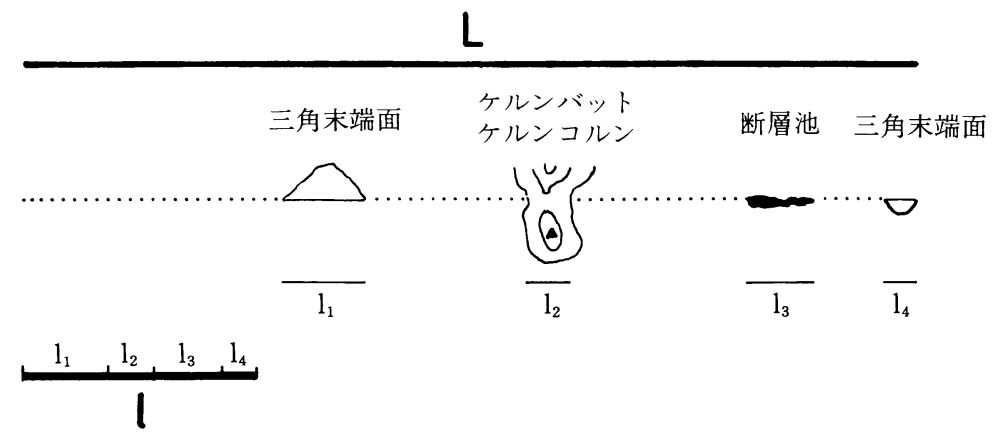

第 9 図 $L, \quad l i$ 及び $l$ の関係

点線部は，抽出するか否かを決定するための判断基準となっていない部分である。

となる。さらに，(8)式の両辺の対数をとると， $\log P(l)=\log P(p 1)+\log P(2)+\log P(p 3) \cdots \cdots$

となる。各 $P(p i)$ が独立で有限な值をとると考えられ るので，中央極限定理によって右辺はガウス分布に漸 近し, 従って確率 $P(l)$ の分布は対数正規分布をなす であろう11)。

$$
P(l)=\frac{1}{\sqrt{2 \pi} \sigma l} \times \exp \left[-\frac{(\log l-\mu)^{2}}{2 \sigma^{2}}\right]
$$

$$
(\mu, \sigma: \text { 定数) }
$$

長さ $L$ の画像上のリニアメント（第 3 集団）が第 4 集 団のリニアメントとして認識抽出される確率 $Q(L)$ は, $l$ の最小值から $L$ までの $P(l)$ を積分することに よって求められる。なぜならば, 長さ $L$ のリニアメン 卜（第 3 集団）が多数存在し，それぞれが様々な長さ の $l(l \mathrm{~min} \sim L)$ によってリニアメント（第 4 集団）と して判断され抽出されるとすれば，lがとり得る值の 区間について $P(l)$ の総和をとればよいからである。 よって,

$$
\begin{aligned}
Q(L) & =\int_{l_{\min }}^{L} P(l) d l \\
& =\int_{l_{\min }}^{L} \frac{1}{\sqrt{2 \pi} \sigma l} \times \exp \left[\frac{(\log l-\mu)^{2}}{2 \sigma^{2}}\right] d l
\end{aligned}
$$

となる(第10図)。これは，累積対数正規分布を表す式 であり，このような理由により確率 $Q(L)$ は累積対数 正規分布で近似されると考えられる。

さらに，第 3 集団のサイズ分布 $n_{3}(L)$ にこの確率 $Q$ (L) を掛けることによって第 4 集団のサイズ分布 $n_{4}$ (L)になる。

$$
n_{4}(L)=n_{3}(L) \times Q(L)
$$

第 3 集困のサイズ分布 $n_{3}(L)$ （もしくは，累積サイ $-10-$

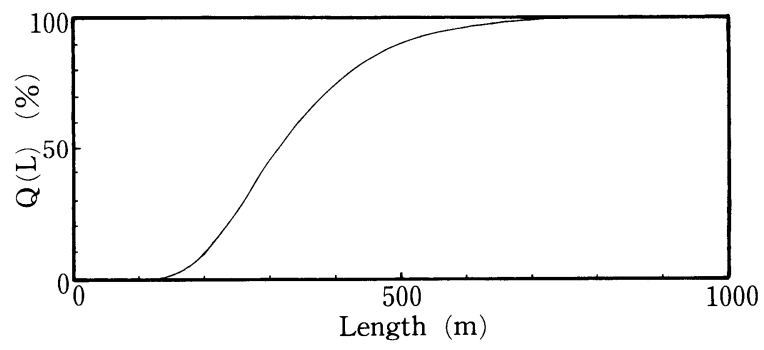

第10図 画像上のリニアメントの長さのリニアメント業認 識抽出される確率 $\mathbf{Q}(\mathrm{L})$

ズ分布 $\left.N_{3}(L)\right)$ は，3.4で述べたように求めることがで きない。そこで，累積サイズ分布・サイズ分布におい て，第 3 集団のサイズ分布 $n_{3}(L) \fallingdotseq$ 第 2 集団のサイズ 分布 $n_{2}(L)$ (もしくは，第 3 集団の累積サイズ分布 $N_{3}$ $(L) \fallingdotseq$ 第 2 集団の累積サイズ分布 $\left.N_{2}(L)\right)$ と見なすこ とができると仮定する。すると，(13)式は，

$$
n_{4}(L) \fallingdotseq n_{2}(L) \times Q(L)
$$

と，書き換えられる。さらに，(7')式，(12)式より

$$
\begin{aligned}
& n_{4}(L) \fallingdotseq c^{\prime} \times L^{-(\mathrm{D}+1) \times} \\
& \int_{l \text { min }}^{L} \frac{1}{\sqrt{2 \pi} \sigma l} \times \exp \left[-\frac{(\log l-\mu)^{2}}{2 \sigma_{2}}\right] d l \\
& \quad\left(c^{\prime}, \mu, \sigma \text { ：定数 }\right)
\end{aligned}
$$

が得られる。

この (15) 式を用いて理論分布を示したものが第 7 困 $\mathrm{b}$ (サイズ分布)，第 8 図 b (累積サイズ分布) である。 これらの図は, 第 7 図 $\mathrm{a}$, 第 8 困 $\mathrm{a}$ の実際のデー夕分布 に対して，(15)式のパラメータ $(c, \mu, \sigma)$ を変化さ せて肉眼的にべストフィットしたものである。 


\section{4.リニアメントのサイズ分布の差と その発生要因の考察}

\section{1 グランドベースェフェクト（A-factor）}

グランドベースエフェクト（A-factor）は，断裂系 （第 1 集団）から地表面上のリニアメント（第 2 集団） に至る過程と定義される。

A-factorには，少なくとも $4 つ(A-1 \sim A-4)$ の 影響が考えられるが，累積サイズ分布において最もそ の影響が強いのは，3.3で前述したように，その分布が 直線状ではなくやや上に凸の曲線となっていることか ら考えて，A-1「断裂の破砕帯が大きいものほど地表 面に現れやすい。」であろう。

なお，第 4 図(b) 及び第 6 図で推定した第 2 集団の 曲線は, 第 6 図の分布の包絡線よりもやや上側 ( $\mathrm{y}$ 軸方 向性の向き)に位置しているが，これは C-1の影響を 考慮したためである。

\section{2 イメージベースェフェクト（B-factor）}

イメージベースエフェクト（B-factor）は，地表面 上のリニアメント（第 2 集団）から画像上のリニアメ ント（第 3 集団）に至る過程と定義される。

B-factorには少なくとも $4 つ(B-1 ＼mathrm{~ B-4) の 要 素 ~}$ が考えられ，その結果として累積サイズ分布にその影 響が現れる。しかしながら，現段階においては，この 累積サイズ分布を推定することは困難であるため，別 の機会に考察したい。

\section{3 ヒューマンェフェクト（C-factor）}

ヒューマンエフェクト (C-factor) は, 画像上のリ ニアメント（第 3 集団）から認識抽出されたリニアメ ント（第 4 集団）に至る過程と定義される。

第 4 集団の累積サイズ分布を表わしているのは第 4 困 (c)であるが, これは，第 5 図 bの実測值より描いた 曲線である。この図から第 4 集団と第 2 集団（もしく は第 1 集団）との間には大きな差異があることが分か る。このような差異を生み出す最大の原因は，3.5で前 述したようにC-factor のうちのC-1「人間の目によ る抽出においては長いリニアメントほど認識抽出され やすい。」であろう。

さらに，C- 1 以外の影響も観察できる。第11図は， 第 7 図 $\mathrm{a}$ と第 7 図 b を同一両対数ブラフ上にのせた

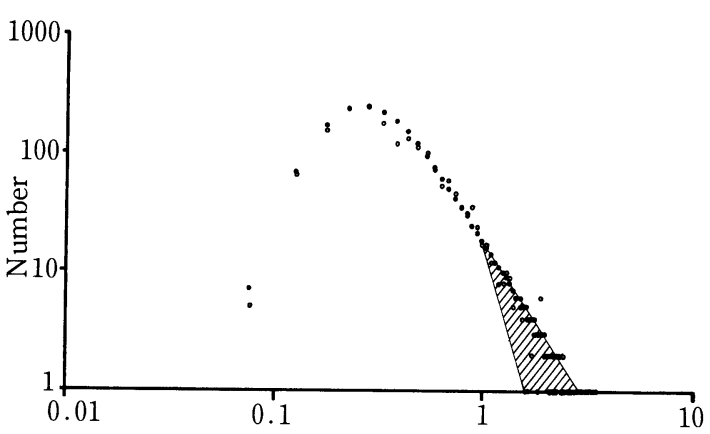

第11図 北海道大夕張地域の空中写真のサイズ分布とその 理論分布

白丸：実測值，黒丸：理論值

ものである。第11図中の斜線部は，C- $2\lceil A-3$ によっ て一本の断裂が複数の地表面上のリニアメントとして 現れたものを，観察者の条件により，その一群のリニ アメントを一本とみなしたり,複数とみなしたりする」 およびC-3「画像の大きさには限界があるので画像上 のリニアメントのうち長くかつ幅の広いものは, 認識 されにくい」の影響によるものと考之られる。斜線部 の中で比較的長さの短い側では C- 2 の影響が, 長い側 では C-3の影響が強いと考えられる。

ここで, C-2の影響はやや複雑であり説明が必要で ある。これは，観察者の条件により，ある一群のリニ アメントを一本とみなしたり，複数とみなしたりする ため，その条件によりそのどちらか一方(今回の場合， 複数とみなす方）だけに偏るためであろう。すなわち これは，断裂の性状によるもので，観察のスケールの 違いにより生じるものである。

断裂は, 細かくみた場合, 地表面上との交線が一筋 の線をなすのではなく，一般には第12図 a に示すよう な断裂群をなすことが多い22),23)。このような断裂群は 複数の断裂に見えるが粗視化してみれば一本の断裂に も見える(第12図 b)。このことは，リニアメントも同 様にいえる。第12図bがリニアメントとして現れると きは第12図 c のような形態をなすことが多く，スケー ルの違いによって一本にも複数にも数えることができ る。

つまり，観察者のスケールと断裂の規模との関係に よって，C-2 の影響の仕方に変化が現れるわけであ る。ある一定のスケール下の観察において,そのスケー ルに対して相対的に十分に長いリニアメントには C - 2 の影響が強く働き,こうした長いリニアメントのほ 


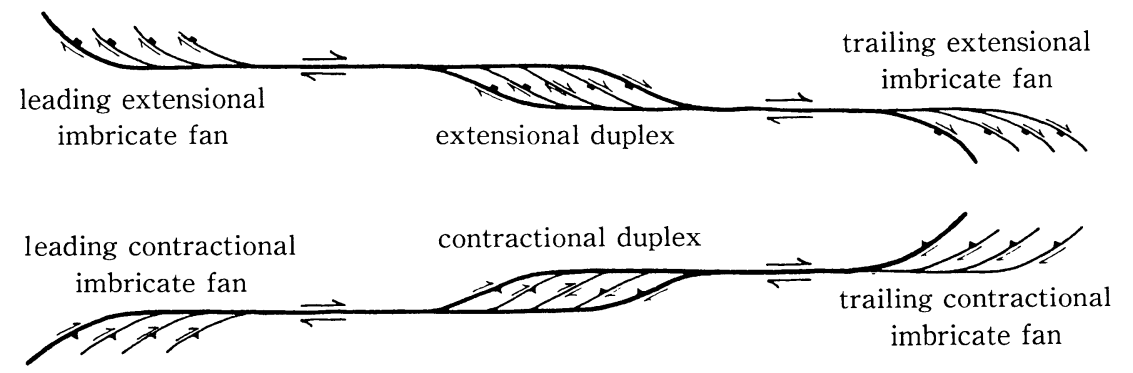

(a) 理想的な断裂の右ずれ strike-skip system ${ }^{22}$

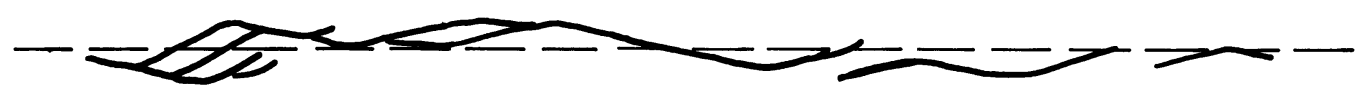

(b) 断裂群 (第 1 集団)
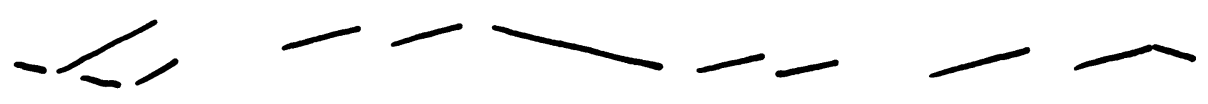

(c) 地表面上のリニアメント群(第 2 集団)

\section{第12図 断裂群}

とんど複数の断裂とみなすようになる。よって，相対 的に長いリニアメントは, その頻度を減じる。この減 少分が第11図の斜線部に当たる。

\section{5.まと め}

画像データから抽出されたリニアメントの累積サイ ズ分布・サイズ分布について考察し, 以下の結論を得 ることができた。

1)リニアメントは, その抽出過程において第 3 困 に示すような様々な影響を受ける。これを，説明する ために抽出過程を 3 段階に区分し，それぞれの間に 4 つの集団を仮定した。

2）リニアメントの累積サイズ分布は, 第 4 困に示 すような変化を示す。

第 1 集団では, 両対数上で直線分布を示してそのフ ラクタル次元 $D$ はほぼ 2 である。

第 2 集団では, 緩やかな曲線分布を示しリニアメン トの長さが長い方に行くにしたがいそのフラクタル次 元 $D$ は 2 に近ずき, 短い方にいくにしたがい $1.6 \sim 1.8$ まで減少する。
第 4 集団においては, 第 4 図(c)に示すような特徽的 な，上に凸の曲線分布を示す。

3）累積サイズ分布・サイズ分布に変化をもたらす 原因について考察し, 各抽出過程における諸効果につ いて次のような結果を得た。

第 1 集団から第 2 集団に至る過程においてはA -1「断裂の破砕帯が大きいものほど地表面に現れやす い。」の影響が強く，さらに第 2 集団より第 4 集団に至 る過程にあたっては，C-1「人間の目による抽出におい ては長いリニアメントほど認識抽出されやすい。」, C

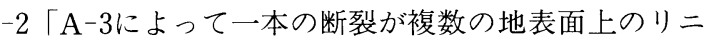
アメントとして現れたものを，観察者の条件により， その一群のリニアメントを一本とみなしたり, 複数と みなしたりする」およびC-3「画像の大きさには限界が あるので画像上のリニアメントのうち長くかつ幅の広 いものは，認識されにくい。」の影響が考えられた。

この中では, とくに C-1の影響が強く, 第 4 集団の理 論分布は，この影響を考え以下の式で与えることがで きる。 


$$
\begin{aligned}
& n_{4}(L) \fallingdotseq c^{\prime} \times L^{-(\mathrm{D}+1)} \times \\
& \int_{l \min }^{L} \frac{1}{\sqrt{2 \pi} \sigma l} \times \exp \left[\frac{(\log l-\mu)^{2}}{2 \sigma^{2}}\right] d l
\end{aligned}
$$

ここで, $n_{4}(L)$ は抽出されたリニアメントの頻度, $L$ は リニアメントの長さ, $l$ は長さ $L$ リリアメントを判断 するための長さ， $c^{\prime} ， \mu, \sigma は$ 定数である。

この研究によって, リニアメントの抽出過程におけ る様々な影響を, システマティックに描くことができ, さらに，累積サイズ分布の変化を明確にすることがで きた。これは, 統計解析によるリニアメントの定量的 評価の可能性を広げるであろう。例えば, リニアメン トの統計解析を行う場合, 人間の眼または自動抽出に よって取得されたりニアメントの累積サイズ・サイズ 分布がこの研究によって求めた理論的な累積サイズ・ サイズ分布に近似していれば，そのリニアメントの定 量的評価の信頼性も高くなる。

累積サイズ分布の第 2 集団，第 3 集団についてはま だ多くの問題を残しており,さらに追求する必要があ る。また,この定量的評価の可能性を広げるためにも， リニアメントの抽出過程における影響について, 累積 サイズ・サイズ分布の観点以外からもその影響につい て研究がなされることが望まれる。

\section{引用文 献}

1) 土田聡, 1987 ：リニアメントの長さの頻度分布, 写真測 量学会昭和62年秋季学術講演会発表論文集, 229-234。

2 ) Tsuchida, S., Yamaguchi, Y. and Hase, H., 1988 : Investigation of Lineaments from Remote Sensing Data, International Archives of Photogrammetry and Remote Sensing, 27, B7, commisionVII, 619-628.

3) Nür, A. 1982: The origin of tensile fracture lineaments, Jour. Struc. Geol., 4, 1, 31-40.

4 ）山口靖·長谷紘和, 1983 : 多様な画像によるリニアメン 卜頻度の解析ーレーダ画像の屋久島地域の適用例につい て一, 写真測量とリモートセンシング, 22, 3, 4-13。
5 ) Hobbs, W.H., 1904 : Lineaments of Atlantic Border region, Bull. Geol. Soc. Amer., 15, 483-506.

6 ) O' Leary, D.W., Friedman, J.D. and Pohn, C.A., 1976 : Lineament, linear, lineation: Some proposed new standard for term, Bull. Geol. Soc. Amer., 87, 1463 -1469 .

7 ) Bates, R.L. and Jackson, J.A., 1987 : Glossary of Geology-3rd, Amer. Geol. Inst., 788pp.

8 ）山口靖・長谷紘和, $1982 ：$ レーダ映像法による日本全国 の地熱資源調査, 測量, 3, 12-20。

9 ）長谷紘和・山口靖・村岡博文, 1983 ：地形・地質情報と してのリニアメント, 月刊地球， $5 ， 11 ， 695-699$ 。

10）鈴木増雄, 1986 : 「次元」の概念の拡張, 別冊数理科学 「形・フラクタル」, 109-117。

11）高安秀樹, 1986 : フラクタル, 朝倉書店, 186pp.

12）川上伸一・水谷 仁・高木靖彦, 1986 ：衝撃破壊におけ る破片のサイズ分布, 数理地震学, 統計数理研究所, 148-159。

13）高安秀樹, 1986 : 破壊のフラクタル, 数理地震学, 統計 数理研究所, 60-62。

14) Fujiwara, A., Kamimoto, G. and Tsukamoto, A., 1977 : Destruction of Basaltic Bodies by High-Velocity Impact, Icarus, 31, 277-288.

15) 水谷仁, 1980 : クレータの科学, 東京大学出版会, 168 pp.

16) Matsushita, M., 1985: Fractal Viewpoint of Practure and Accretion, Jour. Phys. Soc. Japan, 54, 3, 857-860.

17）宇津徳治, 1977 : 地震学, 共立出版, $310 \mathrm{pp}$.

18）伊藤敬祐, 1987 : 宇宙と地震のフラクタル構造, フラク 夕ル科学一高安秀樹編, 朝倉書店, $258 \mathrm{pp}$.

19）山科健一郎, 1987 : 地震活動の性質, 地震の事典一宇津 德治ほか編, 朝倉書店, 150-191.

20）大野博之・亀谷祐志・小島圭二，1987：岩盤割れ目に見 るフラクタル性, 日本応用地質学会昭和 62 年度研研究発 表会講演論文集，57-60。

21) Gutenberg, B. and C. F. Richter, 1944 : Frequency of eartquakes in California, Bull. Seism. Soc. Amer. 34, 185-188.

22) Woodcock, N. H. and Fishcjr, M., 1986 : Strike-Slip duplxes, Jour. Struc. Geol., 8, 7, 725-735.

23) Naylor, M.A., Mandel, G. and Sijpesteijn, C.H.K., 1986: Fault geometries in basement-induced wrench faulting under different, Jour. Struc. Geol., 8, 7, 737 -752 . 